\title{
BENEFITS OF FINANCIAL TRAINING TO INCREASE FINANCIAL LITERACY IN SMALL AND MEDIUM ENTERPRISES
}

\author{
Darman*, Mukhtar Tallesang \\ Faculty of Economics and Business, University of Tadulako, Indonesia \\ *E-mail: darman tadulako@yahoo.com
}

\begin{abstract}
This research aims to analyze the benefit of financial training to improve the financial literacy of small business. The researcher uses experiment research. The research object is the creative industry actors of Donggala woven sarong. Analysis tools used is a descriptive statistic. The research results show that the level of financial literacy of small business actor is said to be low before following financial training. After the treatment in the form of financial training for five days, the financial literacy level has increased. The increase of literacy amounted to 12.2 points (insurance), 18.2 points (investment), 19.8 points (debt), 9.0 points (saving), and 23.6 points (financial statements) respectively. The highest literacy increase among the five literacy aspects is financial statement literacy. This fact shows that financial training has the benefit to increase the financial literacy of small business actor.
\end{abstract}

\section{KEY WORDS}

Financial training, financial literacy, small business.

Financial literacy is the knowledge about financial and the ability to apply it to achieve welfare (Anastasia and Suramaya, 2013). Therefore, financial literacy can be said as fundamental needs for everyone in order to avoid financial issues. Having financial literacy is a vital thing to obtain a prosperous life.

Nunoo and Andoh (2012) stated that financial literacy is one of the determining factors in developing small business in Ghana. Pulungan (2017) stated that financial literacy affected the financial behavior of the community; good financial literacy will lead to good behavior in financial management and vice versa. Mukhtar et al. (2017) stated that financial training affected the level of financial literacy of small business actors.

One of the small businesses that should be given more serious attention is creative industry actors of Donggala woven sarong. The creative industry is the cultural heritage of the community managed hereditary and it is one of the important things to be developed. However, it is now experiencing deterioration and it is almost extinct. This condition is caused by a lower level of knowledge and ability for business financial management.

Based on the opinion of Nunoo and Andoh (2012), Pulungan (2017), and Mukhtar et al. (2017) therefore, it is necessary to do the treatment for financial training to the creative industry actors of Donggala woven sarong as an effort to improve the financial literacy to influence the business growth and community welfare. This research is different from the previous research (Nunoo and Andoh, 2012; Pulungan, 2017) because this research uses an experiment method on the business actors through financial training in one certain room.

\section{LITERATURE REVIEW}

Financial literacy is the knowledge of financial management and the ability to practice it (Lusardi and Mitchell, 2007). Another definition is that financial literacy as the ability to apply financial knowledge in financial management to establish economic welfare (The President Advisory Council of Financial Literacy, 2008). Therefore, financial literacy is not only financial knowledge but also the ability to practice it in business financial management.

Financial literacy consists of four aspects namely (1) General personal financial knowledge covering the understanding of the basic financial knowledge. (2) Saving and debt cover the knowledge of saving and debt. (3) Insurance covers the basic knowledge of 
insurance. (4) The investment covers the knowledge of investment and investment risk (Chen and Volpe, 1998). Other opinion stated that financial literacy generally consists of the knowledge on budgeting, saving, debt, and investment (Remund, 2010).

Nyamboga et al. (2014) conducted research on financial literacy on 30 small businesses in Ngara. The research results show that financial statement, credit management, and budgeting skill significantly affect the ability of small business to pay the debt. This research suggests that small business has to follow the financial related program to improve their capacity. The government and other industry actors should emphasize the importance of financial skill in managing their business.

The Financial Services Authority of the Republic of Indonesia (2013), the important mission of this financial literacy program is to educate the community in managing the finance smartly to improve the knowledge and ability in managing the finance as well as influencing the community welfare. The financial literacy program is expected to realize high financial literacy of Indonesian. Thus, they will have the knowledge of finance and they will know how to apply it to improve welfare.

Based on several aforementioned understanding of financial literacy, financial literacy in this research means the knowledge of insurance, investment, debt, saving, and financial statement.

\section{METHODS OF RESEARCH}

This research uses experimental research to analyze the benefit of financial training to improve the financial literacy of small business. The researcher filters financial literacy for the business actors who have a low level of financial literacy through treatment control of financial training. The benefit of financial training treatment is measured using a structured questionnaire from the chosen research sampling. The questionnaire consists of questions on insurance, investment, debt, saving, and financial statement. The level of financial literacy is measured based on the total of the percentage of the correct answer, with the criteria: $<60 \%$ (low), 60\%-79\% (medium), $\geq 80 \%$ (high). The research object is the creative industry actors of Donggala woven sarong. The chosen research sampling is 15 people. The analysis tool used is a descriptive statistic to analyze the change of financial literacy before and after following the financial training.

\section{RESULTS AND DISCUSSION}

The financial training of small business was conducted for 5 days with 1 material per day. The first day was about insurance and the next day was about investment, debt, saving, and financial statement. Before conducting the training, the participants were given the questionnaire to test the level of financial literacy on investment, debt, saving, and financial statement. The results testing in the level of financial literacy of the participants before the training began are presented on the following figure 1.

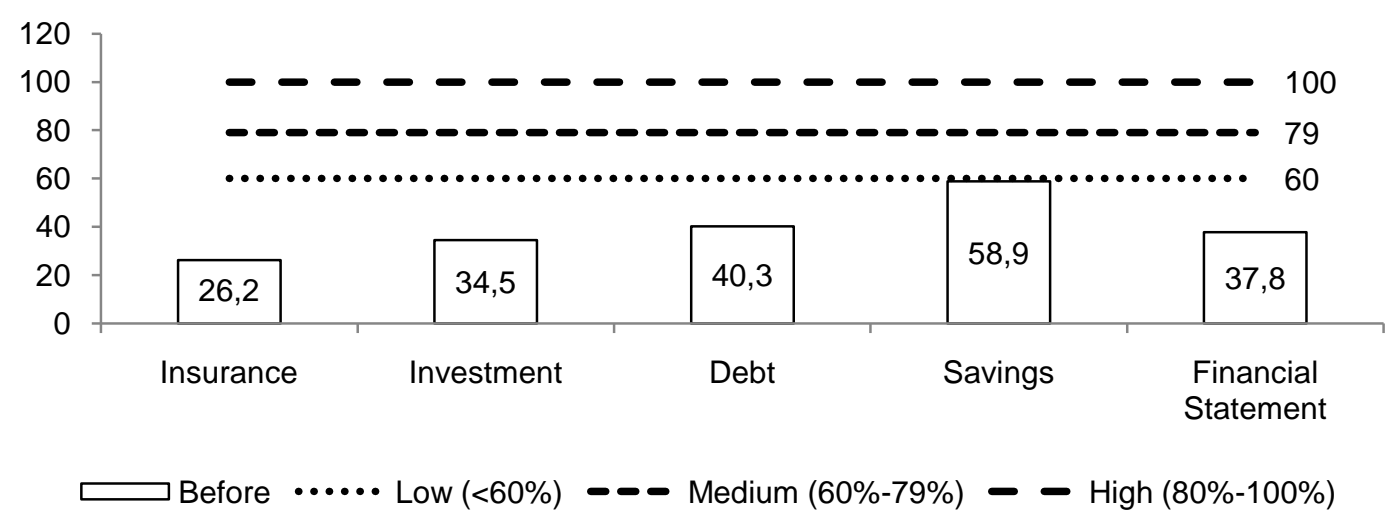

Figure 1 - Level of Financial Literacy before Financial Training, \% (Source: Processed Data, 2018) 
Generally, the level of financial literacy of the participants was low. The total average of participants' correct answers was below $60 \%$ or in the low category. These are in term of insurance, investment, debt, saving, or financial statement knowledge. However, the participants' knowledge on saving $(58.9 \%)$ was close to medium criteria $(60 \%)$. This fact becomes one of the causes of deterioration of Donggala woven sarong industry.

This condition is expected to change after the treatment in the form of financial training. The financial training was done through knowledge and skill sharing on the financial management in form of insurance, investment, debt, saving, and financial statement knowledge. Financial training was conducted in one room by giving financial literacy materials for 5 days to the participants. After financial training, retesting for participants' financial literacy level was conducted. The results testing in the level of financial literacy of the participants after the training are presented in the following figure 2.

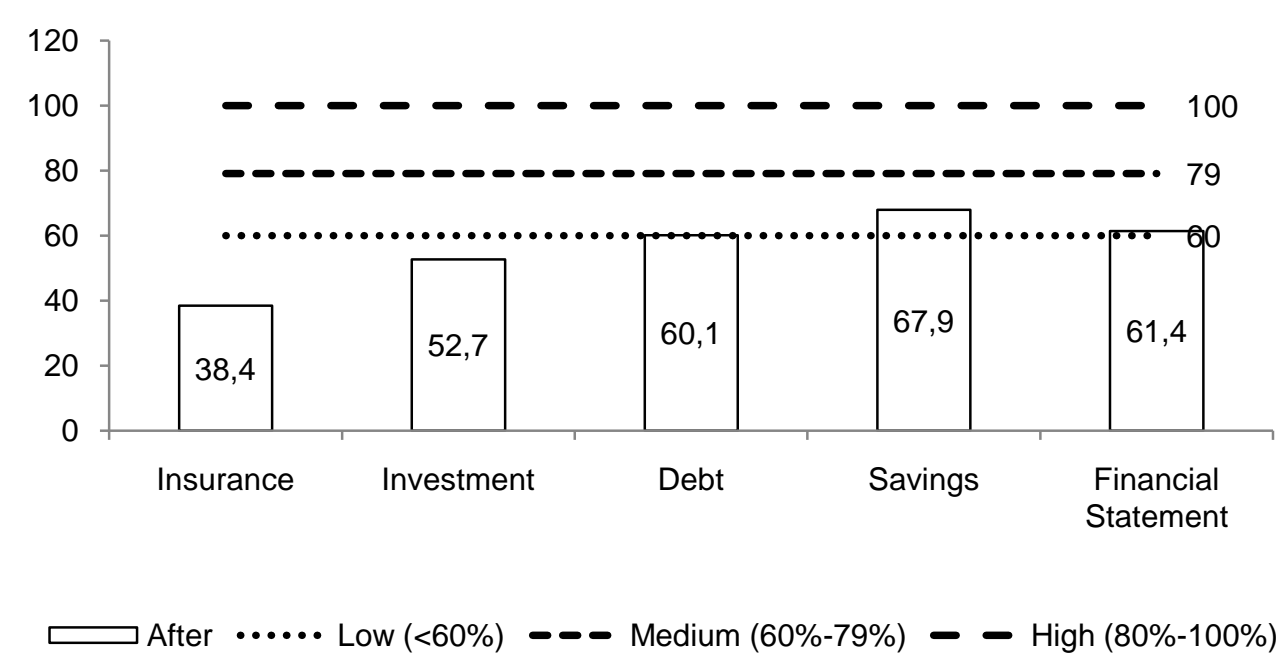

Figure 2 - Level of Financial Literacy after Financial Training, \% (Source: Processed Data, 2018)

After conducting financial training, there is an increase in financial literacy of all aspects, especially debt, saving, and financial statement aspects. These three aspects of financial literacy have improved from low to medium criteria. This condition indicates that the participants can easily understand and apply the knowledge on debt, saving, and financial statement. The reason is that these three aspects are problems commonly faced by the small business of Donggala woven sarong in running their business.

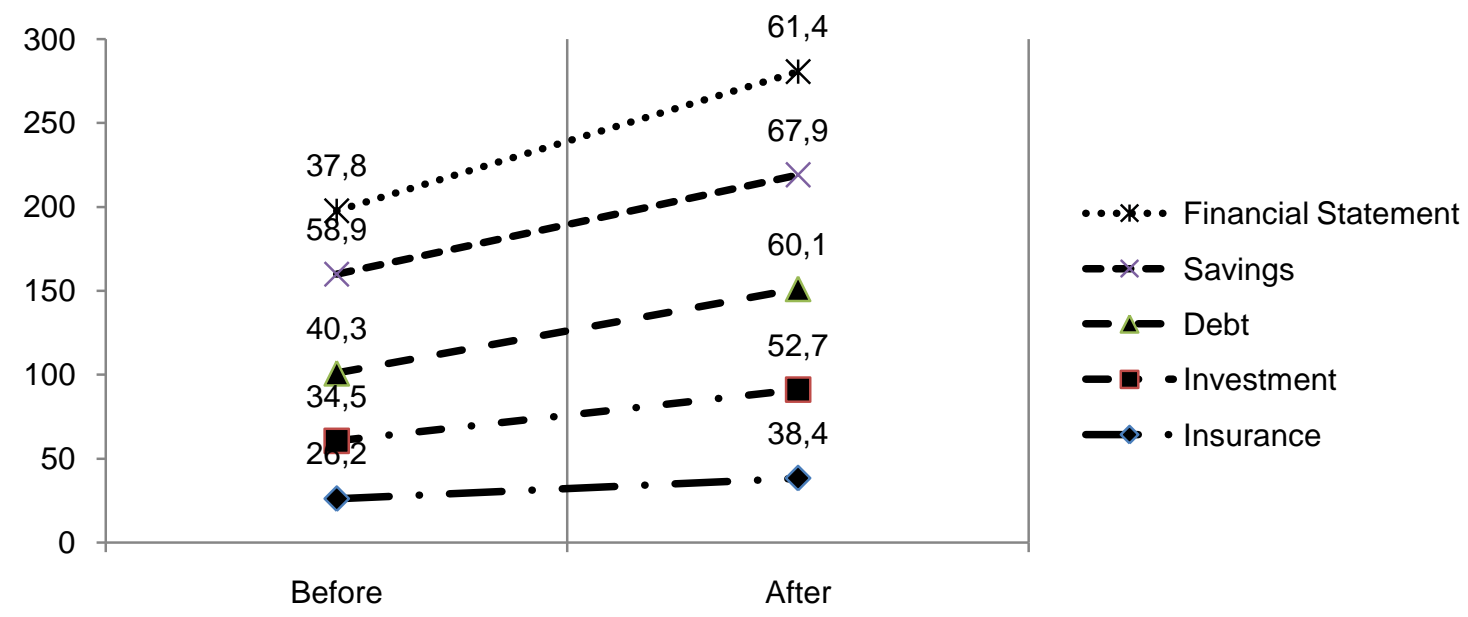

Figure 3 - Comparison of Literacy Levels: Before and After Financial Training, \% (Source: Processed Data, 2018) 
The level of financial literacy of small business actors has improved after following the financial training. The increase of literacy amounted to 12.2 points (insurance), 18.2 points (investment), 19.8 points (debt), 9.0 points (saving), and 23.6 points (financial statements) respectively. The highest literacy increase among the five literacy aspects is financial statement literacy, thus, this fact indicates that financial training can be beneficial to improve the financial literacy of small business. The research results are in accordance with the research results conducted by Nyamboga et al. (2014) who recommended that small business actors should follow a financial program to improve their financial capacity.

\section{CONCLUSION}

The level of financial literacy of small business was said to be low before following the financial training. After the treatment in the form of financial training for five days, the financial literacy level has increased. The increase of literacy amounted to 12.2 points (insurance), 18.2 points (investment), 19.8 points (debt), 9.0 points (saving), and 23.6 points (financial statements) respectively. The highest literacy increase among the five literacy aspects is financial statement literacy. The research results show that financial training can be beneficial to improve the financial literacy of small business.

\section{REFERENCES}

1. Anastasia., \& Suramaya. (2013). Level of Financial Literacy among Students STIE Musi. Jurnal Economia, 9(2)

2. Nunoo, J., \& Andoh, F. K. (2012). Sustaining Small and Medium Enterprises through Financial Service Utilization: Does Financial Literacy Matter? Selected Paper Prepared for Presentation at the Agricultural and Applied Economics Association's 2012 AAEA Annual Meeting Seatle, Washington.

3. Pulungan, D. R. (2017). Financial Literacy and Its Impact on the Financial Behavior of the People of Medan City. Jurnal Ekonomikawan, 17(1),

4. Mukhtar, T., Evvy, R., \& Darman. (2017). The Role of Financial Literacy in Creative Industry Growth: Women Entrepreneur Study of Donggala Woven Fabric Industry. RJOAS, 9(69),

5. Lusardi, A., Mitchell, O. S. (2007). Financial Literacy and Retirement Planning: New Evidence from the Rand American Life Panel, JEL classification: D91

6. The President's Advisory Council of Financial Literacy. (2008). Annual Report to the President, Executive Summary

7. Chen, H., \& Volpe, R. P. (1998). An analysis of personal financial literacy among college students. Financial Services Review, 7(2), 107 - 128.

8. Remund, D. L. (2010). Financial Literacy Explicated: The Case For A Clearer Definition In An Increasingly Complex Economy. Journal of Consumer Affairs, 44(2),

9. Nyamboga, T. O., Benson, O. N., Abdi, M. A., Felistus, N., \& Gongera E. (2014). An Assessment of Financial Literacy on Loan Repayment by Small and Medium Entreprnuers in Ngara Nairobi County. Research Journal of Finance and Accounting, 5(12),

10. The Financial Services Authority of the Republic of Indonesia. (2013). Financial Customer Care, Consumer Education Magazine, August 2013 Edition, Th. I. 